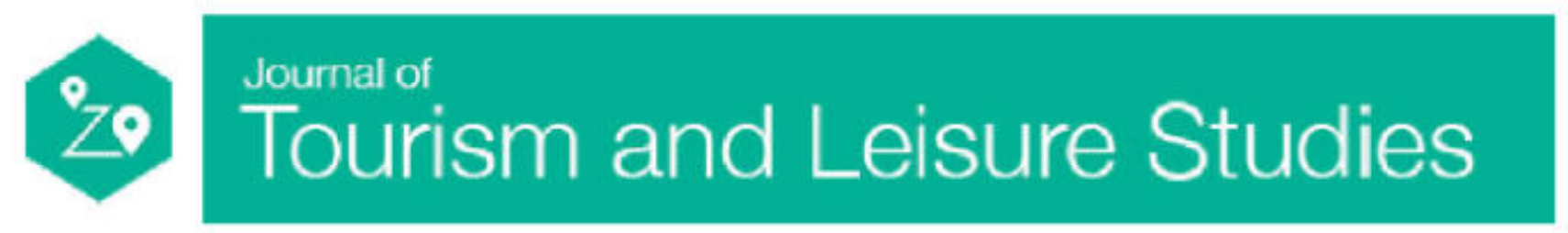

\title{
An Analysis and Comparison of Expectations and Perceptions on Sustainable Tourism among Italian and German Tourists
}

\author{
By Vincenzo Russo, Anna Re, Aurelio Angelini and Davide Jabes. \\ Published by Journal of Tourism and Leisure Studies
}

\begin{abstract}
The paper investigates the relationship of Italan and German consumers with sustainable tourism through a quantitative onine questionnaire. The study's first aim is to understand the representation of sustainable tourism. It also analyzes if the issue of sustainablity denotes an abstract or concrete value to consumers, the extent to which susta nablity is considered an important factor in the process of purchasing and consumpton of a tourism product, and then becomes a driver for consumers to choose from, The analysis of tourist thws and the literature of the field have shown that in Germany there is extensive experience on the topics of sustainability and sustainable tourism, while little has been written on these issues with respect to Italian tourists. The key dimensions of the questionnaire were based on an analysis of the scientfic literature of the field and on an earler qualtative phase carried out through interviews with opinion leaders that have identified main themes, values, expectations, and needs of the consumer of tourism. The questionnaire was divided into three parts: the frst explores the sociondemographic characteristics and values, the second tourism habits, the third knowledge, perceptons, attitudes, and behaviors. The results provide a better understanding of the drivers that influence the choice of tourism and have important practical implcations for the implementation and communication of sustainable tourism.
\end{abstract}

Keywords: Sustainabillty, Tourism, Economics

Journal of Tourism and Leisure Studies, Volume 1, Issue 1, March 2016, pp. 1-11. Avticle; Print (Spiral Bound), Published online: January 27,2016 (Article: Electronic (PDF File; 681.392KB)). 


\title{
An Analysis and Comparison of Expectations and Perceptions on Sustainable Tourism among Italian and German Tourists
}

\author{
Vincenzo Russo, IULM University of Milan, Italy \\ Anna Re, IULM University of Milan, Italy \\ Aurelio Angelini, University of Palermo, Italy \\ Davide Jabes, IULM University of Milan, Italy
}

\begin{abstract}
The paper investigates the relationship of Italian and German consumers with sustainable tourism through a quantitative online questionnaire. The study's first aim is to understand the representation of sustainable tourism. It also analyzes if the issue of sustainability denotes an abstract or concrete value to consumers, the extent to which sustainability is considered an important factor in the process of purchasing and consumption of a tourism product, and then becomes a driver for consumers to choose from. The analysis of tourist flows and the literature of the field have shown that in Germany there is extensive experience on the topics of sustainability and sustainable tourism, while little has been written on these issues with respect to Italian tourists. The key dimensions of the questionnaire were based on an analysis of the scientific literature of the field and on an earlier qualitative phase carried out through interviews with opinion leaders that have identified main themes, values, expectations, and needs of the consumer of tourism. The questionnaire was divided into three parts: the first explores the socio-demographic characteristics and values, the second tourism habits, the third knowledge, perceptions, attitudes, and behaviors. The results provide a better understanding of the drivers that influence the choice of tourism and have important practical implications for the implementation and communication of sustainable tourism.
\end{abstract}

Keywords: Sustainability, Tourism, Economics

\section{Introduction}

$\mathrm{S}$ ustainability is a recurring theme associated to economic growth, development, and the increasingly felt need to make economic policies compatible with the aim of protecting the environment and natural resources. The sustainability of development is becoming the key objective of many international economic and social programs (Bologna 2005), thus placing itself as a possible key to the interpretation of some of the most interesting present phenomena.

Sustainable tourism, in particular, has generated interest among consumers, and affects not only their attitudes and perceptions, but also, when they can afford it, their consumption choices. It can also help to influence the process of identity construction of consumers, dealing with their present and future interests, values, and the impact of their actions on the environment. This should hopefully lead to a greater protection of natural resources (Ceci 2005; Galli and Notarianni 2002).

Communication on the subject is perceived as not very effective. Consumers, however, feel they need both information and resonance. In the tourism context a fundamental role is exercised by the processes of diffusion of information and communication that contribute significantly to the construction of the social representation of phenomena (Arcuri and Castelli 1996; Gasparini and Ottaviano 2005; Jodelet 1992), in this case sustainable tourism and possible contamination between the values attributed to it and behaviors (Thøgersen 2005; Thøgersen and Olander 2006). As a matter of fact, media have a decisive role in the education and dissemination of knowledge (Mitra 1999; Kang et al. 1999; Puggelli 2005; Morcellini 1999).

Journal of Tourism and Leisure Studies

Volume \#, Issue \#, Publication Year, www.tourismandleisurestudies.com, ISSN Pending

(C) Common Ground, Vincenzo Russo, Anna Re, Aurelio Angelini, Davide Jabes

Permissions: cg-support@commongroundpublishing.com 


\section{JOURNAL OF TOURISM AND LEISURE STUDIES}

In an attempt to investigate the relationship of consumers with sustainable tourism, we started an analysis that included a series of online interviews (questionnaires) for two groups of subjects:

\section{Italian consumers, and}

\section{Foreign consumers (German).}

The choice of a group of potential German tourists comes from the analysis of tourist flows and the awareness that Germany has extensive experience on the topic of sustainability, allowing us to consider this group as a useful benchmark for Italian tourists (Osservatorio Turismo della Provincia di Milano 2013).

\section{Subjects}

Seven hundred subjects ( 363 females and 337 males, 450 Italians, and 250 Germans), who are regular Internet users and aged between 20 and over 70 (of which 59 percent were between 30 to 50 years old), were interviewed with Computer Assisted Web Interview (Cawi) methodology. Participants in the administration were chosen on the basis of socio-demographic quotas to ensure an acceptable level of reliability as far as the population of the two countries.

\section{Statistical Analysis}

Variables are presented as percentages if categorical or as means and standard deviations if continuous. Non-normally distributed continuous variables are presented as geometric means $(95 \% \mathrm{CI})$. The differences in tested parameters between participants from Italy and Germany were explored using an independent t-test (normally distributed continuous variables), Mann U Whitney test (non-normally distributed variables), or a Chi square $\left(\chi^{2}\right)$ test (categorical variables).

A $\rho$-value of 0.05 and less was considered statistically significant. All analyses were performed using SPSS version 19.0, SPSS Inc., Chicago, IL.

\section{Questionnaire}

Participants were administrated a questionnaire in Italian and German made up of three successive blocks: a first part on socio-demographic data (gender, age, household composition, education level, and income); a second part to evaluate the drivers that guide the choices of holidays; and a third part to assess their perceptions, attitudes, and behaviors toward sustainable tourism.

The section on the drivers of choice used to evaluate the choices of tourist consumption included four batteries of closed questions, of which two had multiple responses: channels used to make a reservation (five answer options), communication channels that influenced the choice (seventeen answer options), a question on what motivates a person to choose a destination for his or her holidays (twenty-two answer options), and one on the habit to ask about the sustainability of the selected structure before booking.

The section focused on sustainable tourism was intended to measure the degree of knowledge with respect to the subject, attitudes, and behaviours acted out. This section consisted of eleven batteries of closed questions, some of which had multiple responses. Of these eleven batteries, four concerned the level of knowledge of the subject: what the consumers meant by sustainable tourism; if tourism was harmful to the environment and why; and the perception of how much sustainable tourism is practiced. The next five were related to attitudes toward sustainable tourism: if the consumers were attracted to this form of tourism; which adjectives 
they would associate to it; elements to be taken into account for a sustainable tourist choice; the impact of sustainability on the tourism economy. The last two concerned the sustainable tourist facilities, their characterizing elements and how these structures should communicate their sustainability.

\section{Results}

Participants from Italy were slightly older than participants from Germany. Both samples are equally distributed between males and females, while with regards the level of education, the percentage of Italian graduates is slightly higher (54.2\% Italians vs. 46.4\% Germans), but both samples have a very high level of education. In both samples more than 80 percent have at least a high school diploma. With respect to income, Germans earn more - on average, 42.2 percent of respondents claimed to earn from 3,000 to 4,999 euro, compared to 25.2 percent of Italian respondents, but this is in line with the average wages in the two countries (Istat 2012). Finally, with regard to the household, there were no major differences between the two samples. Fifty percent of Germans do not have children and 45 percent have one or two, while 47 percent of Italians do not have children and the 47 percent have one or two.

Both samples clearly prefer the Internet ( $68 \%$ of Germans and $61 \%$ of Italians) as a channel for booking. The second choice for both are travel agencies (14\% of Germans against 16\% of Italians), but for this question the observed differences in the answers are not statistically significant $(\mathrm{p}>0.05)$.

As for the main channels of communication that influenced the choice, the first interesting fact to note is that, although the three favorite options are the same for the two samples, Italians are more focused on a few items (the question was a multi-response, where it was possible to specify a maximum of five answers according to a ranking from the most important to the least important, scale 1-5), while among Germans internal variability in the answers is higher. In particular, in the Italian sample the first five options come to 58 percent of total answers, while in the German sample the first five options include only 46 percent of them. For both groups, the most selected answers were "information found on the Internet" (23\% of Italians selected this as the first channel, compared with $20 \%$ of Germans), "offers on the internet" (16\% against $9 \%$ ), and "advice of friends and relatives" ( $8 \%$ versus $10 \%)$. If then there is a very clear predominance of the Internet as a communication channel, this predominance is much more important in the Italian sample, while among Germans the Internet plays a strong but less decisive role.

The next question was about motivational drivers that lead to the choice of a tourist destination, and in this case respondents were asked to select the first five answer options according to a ranking most important/less important (scale 1-5). Also, in this case, the internal variability of the demand is significantly higher in the German sample (out of twenty-two possible answer options, twelve answers were selected among Germans, compared with only seven replies in the Italian sample). As first motivation, the Italian sample chose (including all five response options) "the desire to see a new place" (13\% of the sample), followed by "natural beauty of the place" (12\%) and "low cost" (12\%).

Instead, for the German sample the first choice was "great place to relax" (17\%, compared to $9 \%$ of the Italian sample), followed by "natural beauty of the place" $(11 \%)$ and "the desire to see a new place" (16\%).

Both samples appreciate "a new place" and "natural beauty" rather than "historical/cultural beauty." For Germans, a vacation is more associated with relaxation than for Italians. In contrast, the cost has a bigger impact on Italians, but this can also be explained by the different income of the two samples.

The last question of this section concerned the habit to inquire about the sustainability of the selected structure before booking. Differences emerge between the two samples, and in particular 


\section{JOURNAL OF TOURISM AND LEISURE STUDIES}

Italians look for information significantly more $(\mathrm{p}<0.05)$, with an average (scale $1-5)$ of 3.1 compared to 2.9 of Germans.

The third and last block of questions entered the main topic of the research: sustainable tourism. The first question was about whether or not tourism can be harmful to the environment. Both samples predominantly believe that tourism can be harmful to the environment only in specific areas, but for 55 percent of Germans and only 38 percent of Italians. Moreover, 34 percent of Italians believe that tourism is always a resource, and never a problem, versus 18 percent in Germany. Also different, and even more clear $(\mathrm{p}<0.05)$, the problems that respondents attributed to tourism, for the German sample the greatest damage that tourism can cause is pollution ( $45 \%$, against $22.5 \%$ of the Italian sample), while among Italians, considering Italian housing and building policy, there is a lack of protection of the territory due to speculation (32.5\%, against $18.5 \%$ of the German sample) and low controls.

There are statistically significant differences $(p<0.05)$ as far as the perception of the practice of sustainable tourism: While German consumers believed that sustainable tourism was practiced ( $48.7 \%$ versus $18.4 \%$ of Italians), Italians were more convinced it was little practiced (39.5\%, compared to $11.8 \%$ in Germany). Among Germans, sustainable tourism is more popular as a practice, as a concept, as a holiday option, while for Italians it is still considered a niche tourism, and as far as general public opinion there is a lower awareness of the issue and its features.

There are quite important differences between the two samples in the answers to the question of what is meant by sustainable tourism (Table 1). As seen from the table, although the ranking of the answers is very similar between the two groups, the German sample has a more critical attitude, possibly because of a greater knowledge of the subject, and then if sustainable tourism is first and foremost the protection of the environment and creator of value, it can also damage the natural environment and cause tensions.

Table 1. What Is Meant by Sustainable Tourism?

\begin{tabular}{|c|c|c|c|}
\hline & $\frac{\text { Italian }}{\underline{\text { Sample }}}$ & $\frac{\frac{\text { German }}{\text { Sample }}}{n=250}$ & $p$ value \\
\hline $\begin{array}{l}\text { Protection of the natural environment, } \\
\text { essential ecological processes and } \\
\text { conservation of natural heritage and } \\
\text { biodiversity }\end{array}$ & 4.03 & 3.70 & 0.03 \\
\hline $\begin{array}{l}\text { It damages the natural environment by } \\
\text { constructing buildings, villages, roads, etc. } \\
\text { and taking resources to residents }\end{array}$ & 2.07 & 2.50 & 0.00 \\
\hline $\begin{array}{l}\text { It provides socio-economic benefits to all } \\
\text { stakeholders: creating jobs, opportunities } \\
\text { for trade activities and it improves the } \\
\text { quality of life for residents }\end{array}$ & 3.75 & 3.54 & 0.02 \\
\hline It is a cheap mass tourism & 2.34 & 2.36 & 0.81 \\
\hline $\begin{array}{l}\text { It is attractive and is chosen by many } \\
\text { tourists }\end{array}$ & 3.02 & 3.18 & 0.06 \\
\hline $\begin{array}{l}\text { It respects the socio-cultural authenticity } \\
\text { of host communities, conserves their living } \\
\text { cultural heritage and traditional values, } \\
\text { and contributes to intercultural } \\
\text { understanding and tolerance by } \\
\text { encouraging understanding between } \\
\text { different cultures }\end{array}$ & 3.96 & 3.77 & 0.03 \\
\hline $\begin{array}{l}\text { It causes stress and exacerbates the } \\
\text { conflict between tourists and residents }\end{array}$ & 2.09 & 2.66 & 0.00 \\
\hline
\end{tabular}


To investigate more in depth the different perceptions of sustainable tourism, consumers were asked what adjectives they would associate more easily to the term. As shown in Table 2, both groups consider sustainable tourism "responsible" and "environmentally friendly," but there are also many differences between the two samples. First, Italians associate sustainable tourism to "green," to the environment. This aspect is less relevant in the perception of Germans. From the economic point of view, in Italy it is perceived as more convenient and less expensive, but despite a perception of lower price it is considered quite utopian (good but difficult to practice).

Table 2. What Adjectives You Would Associate More Easily to Sustainable Tourism?

\begin{tabular}{|l|l|l|l|}
\hline & $\begin{array}{l}\text { Italian Sample } \\
\mathrm{n}=450\end{array}$ & $\begin{array}{l}\text { German Sample } \\
\mathrm{n}=250\end{array}$ & $p$ value \\
\hline Ethical & 3.95 & 3.64 & 0.00 \\
\hline Ecological & 4.03 & 3.85 & 0.04 \\
\hline Fair-trade & 3.87 & 3.81 & 0.50 \\
\hline Utopian & 2.87 & 2.70 & 0.06 \\
\hline Fashionable & 3.20 & 3.19 & 0.89 \\
\hline Convenient & 3.13 & 2.62 & 0.00 \\
\hline Modern & 3.73 & 3.62 & 0.16 \\
\hline Expensive & 3.06 & 3.26 & 0.01 \\
\hline Green & 4.00 & 3.68 & 0.00 \\
\hline Responsible & 4.06 & 3.87 & 0.02 \\
\hline
\end{tabular}

The different perceptions are reflected also on the intentions to action: While the Italian sample is particularly attracted by sustainable tourism (a score of 3.8 on a scale of 1 to 5), for the German sample the score decreases to $3.4(\mathrm{p}<0.05)$. Italians know little of the theme, and then idealize it (automatically sustainable tourism becomes more appealing), while among Germans the theme is well known. They know its strength and problems, and thus it generates less "enthusiasm."

The two samples differ substantially with respect to what makes a structure sustainable (in fact, almost all the items examined show a statistically significant difference, where $\mathrm{p}<0.05$ ). For both groups, the most important factor is the ability to contribute to the protection of the natural heritage of the area, together with the use of renewable resources and a low production of waste. While as far as the most significant factors there is an agreement between the two samples (although scores given by the Italian sample are always higher), there are other actions for which there are markedly different ideas, such as the possibility to keep pets or to smoke inside a structure.

Table 3. A Sustainable Tourist Structure...

\begin{tabular}{|l|l|l|l|}
\hline & $\frac{\underline{\text { Italian }}}{\frac{\text { Sample }}{\mathrm{n}=450}}$ & $\frac{\underline{\text { German }}}{\text { Sample }}$ & $p$ value \\
\hline Promotes the well-being of host communities & 4.01 & 3.58 & 0.00 \\
\hline Protects local cultural resources & 4.12 & 3.94 & 0.02 \\
\hline Protects costumers' health and safety & 4.01 & 3.82 & 0.02 \\
\hline Contributes to the protection of natural heritage & 4.18 & 3.95 & 0.00 \\
\hline $\begin{array}{l}\text { Limits energy consumption (energy efficiency of } \\
\text { light bulbs, window insulation, switching off } \\
\text { lights, etc.) }\end{array}$ & 4.08 & 3.87 & 0.01 \\
\hline $\begin{array}{l}\text { Uses renewables (solar, photovoltaic, } \\
\text { geothermal, etc.) }\end{array}$ & 4.18 & 3.92 & 0.00 \\
\hline $\begin{array}{l}\text { Limits water consumption (control flow of water } \\
\text { from taps and showers, limiting the change of }\end{array}$ & 3.99 & 3.86 & 0.11 \\
\hline
\end{tabular}




\section{JOURNAL OF TOURISM AND LEISURE STUDIES}

\begin{tabular}{|l|l|l|l|}
\hline $\begin{array}{l}\text { towels and sheets, proper disposal of waste } \\
\text { water, etc.) }\end{array}$ & & & \\
\hline $\begin{array}{l}\text { Limits the production of waste (recycling, } \\
\text { limiting the use of "disposable" products: not } \\
\text { refillable shampoos and soaps and other non- } \\
\text { reusable as shower caps, brushes, beverage } \\
\text { containers, etc.) }\end{array}$ & 4.15 & 3.94 & 0.01 \\
\hline $\begin{array}{l}\text { Uses eco-friendly substances (detergents and } \\
\text { disinfectants) }\end{array}$ & 4.05 & 3.89 & 0.04 \\
\hline $\begin{array}{l}\text { Promotes communication and environmental } \\
\text { education (provides information on local } \\
\text { biodiversity, landscape and nature conservation } \\
\text { at a local level, etc.) }\end{array}$ & 4.02 & 3.75 & 0.00 \\
\hline Doesn't allow smoking in public areas & 4.01 & 3.53 & 0.05 \\
\hline $\begin{array}{l}\text { Indicates and encourages the use of public } \\
\text { transportation }\end{array}$ & 3.91 & 3.76 & 0.00 \\
\hline Provides bikes for free & 3.91 & 3.67 & 0.01 \\
\hline Uses local food (km 0) & 4.11 & 3.92 & 0.08 \\
\hline Uses organic food or integrated farming & 3.94 & 3.81 & 0.01 \\
\hline Uses Fair-trade food and products & 3.93 & 3.72 & 0.00 \\
\hline Makes the facility accessible to pets & 3.63 & 3.14 & 0.00 \\
\hline $\begin{array}{l}\text { Chooses green architecture for the construction } \\
\text { of the structure }\end{array}$ & 3.91 & 3.59 & 0.00 \\
\hline $\begin{array}{l}\text { Chooses environmentally friendly materials in } \\
\text { construction and furnishings }\end{array}$ & 4.04 & 3.73 & 0.00 \\
\hline $\begin{array}{l}\text { Prepares and uses environmental indicators to } \\
\text { measure green performance }\end{array}$ & 0.76 & 3.74 & 0.81 \\
\hline
\end{tabular}

Table 4 shows the different ways in which a structure that provides sustainable tourism should try to communicate its decisions. We can infer the different maturity of the two samples on the topic. For Italians the first channel is the Internet (the same channel used to find information on tourist locations in general), while for Germans it is also important to cooperate with the region and its residents. Among all the items listed, the only one in which the German sample provides a higher score than the Italian is the ability of the structure to provide sustainability training to internal staff. If a structure is sustainable, the people who are part of it must also act sustainably. There are other significant differences: Italians associate the "green" dimension to sustainability and Germans consider the printing of information materials not very useful and not sustainable.

Table 4. A Tourist Sustainable Structure Communicates Its Choice By...

\begin{tabular}{|l|l|l|l|}
\hline & $\frac{\underline{\text { Italian }}}{\frac{\text { Sample }}{\mathrm{n}=450}}$ & $\frac{\underline{\text { German }}}{\frac{\text { Sample }}{\mathrm{n}=250}}$ & $p$ value \\
\hline $\begin{array}{l}\text { Cooperation with the tourist facilities of the } \\
\text { place (community capacity building) (Aref } \\
\text { 2010) }\end{array}$ & 3.77 & 3.78 & 0.90 \\
\hline $\begin{array}{l}\text { Cooperation with residents (community capacity } \\
\text { building) (Aref 2010) }\end{array}$ & 3.80 & 3.91 & 0.14 \\
\hline $\begin{array}{l}\text { "Green" marketing, products and experiences } \\
\text { that focus on sustainability }\end{array}$ & 3.90 & 3.82 & 0.26 \\
\hline Creation of a "green" brand & 3.77 & 3.50 & 0.00 \\
\hline Green washing & 3.78 & 3.32 & 0.00 \\
\hline $\begin{array}{l}\text { A brochure in the rooms that lists all the green } \\
\text { initiatives, even small, implemented by the }\end{array}$ & 3.90 & 3.52 & 0.00 \\
\hline
\end{tabular}


RUSSO ET AL.: EXPECTATIONS AND PERCEPTIONS ON SUSTAINABLE TOURISM AMONG TOURISTS

\begin{tabular}{|l|l|l|l|}
\hline $\begin{array}{l}\text { property (also indicating certifications if } \\
\text { obtained) and future sustainable projects }\end{array}$ & & & \\
\hline $\begin{array}{l}\text { Publication of the same information on the } \\
\text { company website }\end{array}$ & 3.98 & 3.72 & 0.00 \\
\hline Corporate Social Responsibility (Tuan 2011) & 3.77 & 3.61 & 0.022 \\
\hline $\begin{array}{l}\text { Weekly/monthly flyer, a news page on the } \\
\text { website in the languages understood by guests, } \\
\text { with eco-initiatives in the area (guided tours, } \\
\text { trips, etc.) }\end{array}$ & 3.65 & 3.35 & 0.00 \\
\hline $\begin{array}{l}\text { Links to associations and local environmental } \\
\text { protected areas on the website }\end{array}$ & 3.76 & 3.52 & 0.00 \\
\hline $\begin{array}{l}\text { Information (website, brochures, flyers) on } \\
\text { sustainable transportation }\end{array}$ & 3.88 & 3.71 & 0.025 \\
\hline $\begin{array}{l}\text { At the reception, information on opportunities to } \\
\text { visit the local environment and interesting green } \\
\text { events (visitor environmental management) } \\
\text { (Candrea and Ispas 2009) }\end{array}$ & 3.94 & 3.80 & 0.06 \\
\hline $\begin{array}{l}\text { Careful selection of media contacts, providing } \\
\text { local press, media, press releases with green } \\
\text { initiatives implemented and being implemented }\end{array}$ & 3.69 & 3.54 & 0.035 \\
\hline $\begin{array}{l}\text { Contact list (network, forum, etc.), by creating a } \\
\text { network of actors in the area who share similar } \\
\text { sensitivity (parks, environmental groups, } \\
\text { protected areas, etc.) }\end{array}$ & 3.60 & 3.60 & 1 \\
\hline Training of the staff on sustainability & 3.82 & 3.85 & 0.39 \\
\hline
\end{tabular}

The last questions concerned elements to be taken into consideration when you have to assess the sustainability of a real tourist structure, that is, features to look for in a hotel/territory if you want a sustainable holiday. A greater variability emerges in the responses of the German sample compared to the Italian one. In particular, the average answer (always on a scale of 1-5) for the Italian sample ranges from 3.95 to 4.18, while for the German sample from 3.54 to 4.06. For the Italian sample, all items are considered necessary and extremely important, while among Germans a few things (such as energy saving, which has an economic impact) turn out to be far more important than features such as green architecture or environmental certifications.

Table 5. Factors to Be Taken into Account for a Sustainable Tourist Choice

\begin{tabular}{|l|l|l|l|}
\hline & $\frac{\underline{\text { Italian }}}{\underline{\text { Sample }}}$ & $\frac{\text { German }}{\mathrm{n}=450}$ & $p$ value \\
\hline Energle & $\mathrm{n}=250$ & \\
\hline Organic and/or 0 km products & 4.14 & 3.83 & 0.00 \\
\hline Cleaning (type of detergents, recycling) & 4.04 & 3.92 & 0.14 \\
\hline Not wasting water & 4.16 & 3.98 & 0.01 \\
\hline Construction according to bio-architecture & 4.15 & 4.00 & 0.06 \\
\hline $\begin{array}{l}\text { Environmentally friendly materials in } \\
\text { construction and furnishings }\end{array}$ & 3.95 & 3.59 & 0.00 \\
\hline Saving of electricity & 3.95 & 3.73 & 0.00 \\
\hline Energy-efficient appliances & 4.18 & 4.06 & 0.12 \\
\hline $\begin{array}{l}\text { Environmental certification (Ecolabel, Emas, } \\
\text { etc.) }\end{array}$ & 4.15 & 4.06 & 0.19 \\
\hline
\end{tabular}

The last two questions concerned the relationship between tourism, sustainability, and the environment. Both groups agree that environmental awareness will have positive effects on 


\section{JOURNAL OF TOURISM AND LEISURE STUDIES}

tourism economy (the average in answers for this question is 4.08 Italians and 3.95 for the Germans, always on a scale of 1-5).

As far as sustainability and tourism, and if sustainability represents a resource or not for the economy of tourism, the two groups show some differences: in particular, although both groups are convinced that sustainability is first of all a resource, the score given by the Italian sample is significantly higher $(\mathrm{p}<0.05), 4.11$ (the average of the answers for the Italian sample, always on a scale of 1-5), compared to 3.81 of the German sample (the average of the answers for the Italian sample, always on a scale of 1-5).

\section{Discussion}

The majority of Italians and Germans believe that tourism can be dangerous and damaging to natural resources. Tourism, therefore, is not associated only with positive values, indeed it is often perceived as a potentially harmful activity. It becomes crucial for operators to carefully evaluate their environmental impact, considering that potential customers have awareness of environmental risk-related tourism.

Sustainability is widely associated with positive values for both samples. Environmental issues are widely known and discussed. Today people perceive their value and importance, but unfortunately the impacts on consumption are scarce, although growing.

In this context, a good understanding of the concept of sustainability associated with environmental values emerged, but its relation to social, cultural, and economic development is also growing, in particular among Germans. Sustainability has to be seen as a more complex ethical dimension involving various spheres: culture, society, economy, environment and we can, together, become more intelligent about the ecological impacts of how we live-and how ecological intelligence, combined with marketplace transparency, can create a mechanism for positive change (Goleman 2009; Lansing De Vries 2007).

Almost all of the Italians and Germans would be oriented to choose a sustainable structure. Germans prefer simple structures which, in theory, should be more oriented and suitable to propose sustainable tourism.

However, there is a general inconsistency between the widespread knowledge, beliefs, and opinions, the declared values and behaviours about sustainability: consumers do different and contradictory things compared to what they say they want to do, and often opinions and attitudes are different. Awareness of the role of sustainability does not always coincide with the habits and behaviors of consumers (Biel and Dahlstrand 2005).

Among the reasons that influence the choice of a tourist destination as well as the location and cultural enrichment, people look for "nature" and "a new place" (Italians). Germans are looking for rest and relaxation. Holidays should be a time of rest and pleasure, a form of sensory gratification first.

The Internet is the winning communication channel on all fronts among Italians. It is used for reservations, information on a structure and its sustainable choices. Respondents consider it as a tool through which tour operators should inform and communicate with potential green customers. Even for Germans, the Internet is the winning channel as far as the search of information on sustainable tourist structures. On the Internet you can and must find all the information regarding the services and eco-friendly choices, or at least the respondents expect this. But a structure has also to implement communication strategies by involving local people and its staff.

Particular attention must be placed on the costs. Being sustainable does not mean offering an expensive product, and this is a message that operators must communicate. Very often sustainable actions do not involve additional costs. Recycling, waste reduction, energy conservation, use of local/organic products, etc. are not advertised and communicated. These actions could be very appreciated and encourage consumers' choice. 


\section{RUSSO ET AL.: EXPECTATIONS AND PERCEPTIONS ON SUSTAINABLE TOURISM AMONG TOURISTS}

On the other hand, Germans consider sustainable tourism a viable choice for everybody: It cuts across all classes of interest and practice. There is a slight prevalence of preference and practice in higher classes. It is a widely known and widespread type of tourism and it does not seem to be a niche tourism.

\section{Conclusion}

The analysis of communication and sustainable tourism has led to the identification of similar trends but also conflicting ones in the Italian and German samples. Although tourism can damage the environment, the two samples (especially young people and those belonging to the higher classes) have a positive attitude toward sustainable tourism, perceived as a potential source of economic but also cultural and social development. They are, therefore, available to choose a sustainable structure, despite objective, practical, economic difficulties (Italians).

As a macro difference between the two groups, we noticed that the Italians are less accustomed to sustainable tourism (still tied to the idea of green), while the Germans have developed a multidimensional awareness of the concept of sustainability.

Moreover, the two groups show a growing awareness and widespread interest in sustainable tourism largely associated with positive values. Germans practice sustainable tourism widely, all classes of income and age. In Italy, instead, it is still practiced by a minority and it is considered expensive.

Tourism has an extraordinary potential for growth, especially ecotourism in Italy, and can bring wealth and prosperity especially if it is sustainable. The UN resolution, "Promotion of ecotourism for poverty eradication and environmental protection" (2010), stressed that green tourism can help solve some of the major problems of the contemporary world, from poverty to climate change, and has a positive impact on economy, job creation, and education. It is an opportunity of growth for local economies. It can improve, enhance, and revaluate territories and landscapes, from ancient villages to the small mountain villages, and traditions that hold thousands of years of history and culture. The German sample associates sustainable tourism to the protection of the environment, but also of culture, society, and art. The Italian sample associates sustainability especially to the protection of the environment.

"Sustainable Traveling" reduces the impact on the environment and enriches tourists and local economies. It also helps to rediscover an authentic way to travel, creating a bond with the places we visit and the people we meet. Sustainable tourism can be the new frontier of traveling: a chance to meet new people, experience and ideas, projects and virtuous economies.

But tourism is sustainable when there is attention to the "carrying capacity" of the area we visit; too many people can damage the natural environment and put at risk the survival of those who use that environment as an economic resource. These problems not only affect the natural areas but also urban areas and monuments.

The Internet is the preferred communication channel; it is used for reservations, information on a structure and its sustainable choices and respondents consider it an instrument through which tour operators should inform and communicate with potential green customers. But interpersonal communication still plays an important and irreplaceable role, especially for the German sample. 


\section{JOURNAL OF TOURISM AND LEISURE STUDIES}

\section{REFERENCES}

Arcuri, Luciano, and Luigi Castelli. 1996. La trasmissione dei pensieri: un approccio psicologico alle comunicazioni di massa (The Transmission of Thoughts: A Psychological Approach to the Mass Media). Padova: Zanichelli.

Aref, Fariborz. 2010. "Community Capacity as an Approach for Sustainable Tourism." e-Review of Tourism Research 8 (2): 30-40.

Biel, Anders, and Ulf Dahlstrand. 2005. "Values and Habits: A Dual-Process Model." In Environment, Information and Consumer Behaviour, edited by Signe Krarup and Clifford S. Russell, 33-49. Cheltenham, UK and Northampton, USA: Edward Elgar Publishing Ltd.

Bologna, Gianfranco. 2005. Manuale della Sostenibilità. Idee, concetti, nuove discipline capaci di futuro (Handbook of Sustainability: Ideas, Concepts, New Disciplines for the Future). Milano: Edizioni Ambiente.

Candrea, Adina, and Andreia Ispas. 2009. "Visitor Management, a Tool for Sustainable Tourism Development in Protected Areas." Bulletin of the Transylvania University of Braşov 2 (51): 131-6. Series V: Economic Sciences.

Ceci Rami, Lucilla. 2005. Turismo e sostenibilità (Tourism and Sustainability). Armando Editore: Roma.

Galli, Paolo, and Marcello Notarianni. 2002. La sfida dall'ecoturismo (The Challenge of Ecotourism). DeAgostini: Novara.

Gasparini, Barbara, and Cristina Ottaviano, eds. 2005. Analizzare i media: Tecniche di ricerca per la comunicazione (Analyze the Media: Research Techniques for Communication). Milano: Franco Angeli.

Goleman, Daniel. 2009. Intelligenza ecologica (Emotional Intelligence). Milan: Rizzoli.

Istituto Nazionale di Statistica (Istat). Accessed November 30, 2015. http://www.istat.it.

Lansing, Paul, and Paul De Vries. 2007. "Sustainable Tourism: Ethical Alternative or Marketing Ploy?" Journal of Business Ethics 72 (1): 77-85.

Jodelet, Denise, ed. 1992. Le rappresentazioni sociali (Social Representations. Napoli: Liguori.

Kang, Jong G., Stephen D. Perry, and Seok Kang. 1999. "The Relation between Television Viewing and the Values Orientation of Japanese Student." Mass Communication and Society 2 (3-4): 147-61.

Mitra, Ananda. 1999. "Virtual Commonality: Looking for India on the Internet." In Virtual Culture: Identity and Communication in Cybersociety, edited by Steven G. Jones, 5579. Thousand Oaks, CA: Sage.

Morcellini, Mario. 1999. La tv fa bene ai bambini (TV is Good for Children). Roma: Meltemi.

Osservatorio Turismo Provincia di Milano. Accessed November 30, 2015. http://www.visitamilano.it/turismo/operatori/Osservatorio_del_turismo.

Puggelli, Francesca R. 2005. Spot generation. I bambini e la pubblicità (Spot Generation: Children and Advertising). Milano: Franco Angeli.

Thogersen, John. 2005. "Consumer Behaviour and the Environment: Which Role for Information?" In Environment, Information and Consumer Behaviour, edited by Signe Krarup and Clifford S. Russell, 51-63. Cheltenham, UK: Edward Elgar.

Thøgersen, John, and Folke Ölander. 2006. "The Dynamic Interaction of Personal Norms and Environment-friendly Buying Behaviour: A Panel Study.” Journal of Applied Social Psychology 36 (7): 1758-80.

Tuan, Trong Luu. 2011. "Corporate Social Responsibility and Sustainable Tourism.” Business and Economic Research 1 (1): 1-9.

United Nations Resolution. 2010. "Promotion of Ecotourism for Poverty Eradication and Environmental Protection." Accessed November 30, 2015. http:/www.un.org/ga /search/view_doc.asp?symbol=A/RES/65/173. 
RUSSO ET AL.: EXPECTATIONS AND PERCEPTIONS ON SUSTAINABLE TOURISM AMONG TOURISTS

\section{ABOUT THE AUTHORS}

Prof. Vincenzo Russo: Associate Professor, Department of Psychology, Consumption, and Communication, IULM University of Milan, Milan, Italy

Anna Re: Researcher, Department of Psychology, Consumption, and Communication, IULM University of Milan, Milan, Italy

Prof. Aurelio Angelini: Associate Professor, Department of Psychological Sciences, Pedagogical, and Education, University of Palermo, Palermo, Italy

Dr. Davide Jabes: Researcher, Department of Psychology, Consumption, and Communication, IULM University of Milan, Milan, Italy 